\title{
The Effect of Family Development Session through Family Hope Program on Visit to Integrated Healthcare Center and Child Nutritional Status: A Multilevel Evidence
}

\author{
Nisaus Zakiyah'), Endang Sutisna Sulaeman²), Eti Poncorini Pamungkasari3) \\ 1)Masters Program in Public Health, Universitas Sebelas Maret \\ 2)Department of Public Health, Faculty of Medicine, Universitas Sebelas Maret \\ 3)Faculty of Medicine, Universitas Sebelas Maret
}

\begin{abstract}
Background: The Family Development Session through the Family Hope Program (FHP) uses the nutritional status of toddlers as an indicator of the quality of life that reflects the welfare of the community. This study aimed to analyze the effect of the Family Development Session (FDS) through the Family Hope Program on the child nutritional status.

Subjects and Method: This was an analytic observational study with a retrospective cohort design. This study was conducted in Ponorogo, East Java, from December to February 2020. A sample of 200 children was selected by simple random sampling. The dependent variable was child nutritional status. The independent variables were FDS (FHP), maternal education, family income, social support, maternal knowledge, selfefficacy, complementary food, integrated community health center. The data were collected by questionnaire and analyzed by a multiple multilevel logistic regression.
\end{abstract}

Results: Child nutritional status was positively associated with FDS $(b=1.24 ; 95 \%$ $\mathrm{CI}=0.26$ to $2.22 ; \mathrm{p}=0.014)$, high maternal education $(b=1.18 ; 95 \% \mathrm{CI}=0.16$ to $2.19 ; \mathrm{p}=$ 0.023), family income ( $\mathrm{b}=1.11 ; 95 \% \mathrm{CI}=0.11$ to $2.11 ; \mathrm{p}=0.030)$, social support $(\mathrm{b}=1.57$; $95 \% \mathrm{CI}=0.46$ to $2.67 ; \mathrm{p}=0.006$ ), maternal knowledge $(b=1.24 ; 95 \% \mathrm{CI}=0.26$ to 2.23 ; $\mathrm{p}=0.013)$, self efficacy $(\mathrm{b}=1.38 ; 95 \% \mathrm{CI}=0.32$ to $2.44 ; \mathrm{p}=0.011$ ), complementary feeding $(b=1.35 ; 95 \% \mathrm{CI}=0.33$ to $2.37 ; \mathrm{p}=0.010)$, and regular visit to integrated community health center $(b=1.42 ; 95 \% \mathrm{CI}=0.28$ to 2.56 ; $\mathrm{p}=0.015)$. Integrated health center had strong contextual effects on the child nutritional status with intra-class correlation $($ ICC) $=$ 33.97\%.

Conclusion: Child nutritional status is positively associated with FDS, high maternal education, family income, social support, maternal knowledge, self efficacy, complementary feeding, and regular visit to integrated community health center. Integrated health center has strong contextual effects on the child nutritional status.

Keywords: child nutritional status, integrated healthcare center

\section{Correspondence:}

Nisaus Zakiyah. Masters Program in Public Health, Universitas Sebelas Maret. Jl. Ir. Sutami 36A, Surakarta 57126, Central Java. Email:nizakiyaah@gmail.com. Mobile: +6285235948995 .

\section{Cite this as:}

Zakiyah N, Sulaeman ES, Pamungkasari EP (2020). The Effect of Family Development Session through Family Hope Program on Visit to Integrated Healthcare Center and Child Nutritional Status: A Multilevel Evidence. J Health Policy Manage. o5(03): 224-234. https://doi.org/10.26911/thejhpm.2020.05.03.08.

\section{(c) (i) (2) Journal of Health Policy and Management is licensed under a Creative Commons} Journal of Health Policy and Management is licensed under a Creative
Attribution-NonCommercial-ShareAlike 4.o International License.

\section{BACKGROUND}

The main obstacle to the low quality of human resources is complex, from the aspects of food (nutritional intake), health, education and the labor market (LIPI, 2018). The Conditional Cash Transfers (CCT) Program is the most widely 
implemented social protection system in Indonesia and more than 13 African countries over the past few years. In addition, more than 45 African countries have conditional assistance programs in 2014. Conditional cash transfers provide cash payments to households (mothers or caregivers) that comply with certain conditions, such as requiring children to go to school, and accessing health services (Parsons et al., 2015).

The Conditional Cash Transfers (CCT) program in Indonesia is called the Family Hope Program, called FHP, which is a program for providing conditional social assistance to Beneficiary Families (BF) who are designated as FHP beneficiary families. As an effort to accelerate poverty reduction, since 2007 the Government of Indonesia has implemented FHP.The benefits of FHP are starting to be encouraged to cover people with disabilities and the elderly by maintaining the level of social welfare in accordance with the mandate of the constitution and the President's Nawacita. FHP opens access for poor families, especially pregnant women and children, to take advantage of various health service facilities and educational service facilities (Ministry of Social Affairs, 2017). FHP in 2012 has become a national program, reaching all provinces in Indonesia. Until 2014, it has spread in 34 provinces with 418 districts/ cities and 4870 districts (Ministry of Social Affairs, 2016).

The nutritional status of toddlers is a key instrument for assessing health conditions and early detection of malnutrition (Oliveira et al., 2013). Efforts made to prevent malnutrition are routinely bringing toddlers to IHC. IHC activities include maternal and child health, family planning, immunization and nutrition (Ministry of Health RI, 2012).
Based on the description above, the authors are interested in researching and knowing more about analyzing the influence of the Family Development Session through the Family Hope Program on the nutritional status of toddlers in Ponorogo City.

\section{SUBJECTS AND METHOD}

\section{Study Design}

This study was an observational analytic study with a retrospective cohort design. The study was conducted in Ponorogo Regency, East Java, from December to February 2020.

\section{Population and Sample}

The source population in this study were all chidlren in Ponorogo Regency who participated in 25 integrated community health center. A sample of 200 children was selected by simple random sampling.

\section{Study Variables}

The dependent variable was the nutritional status of toddlers. The independent variables were Family Development Session (FDS), maternal education, family income, social support, maternal knowledge, selfefficacy, complementary foods, toddler visits to IHC and IHC.

\section{Definition of Operational Variable} Family Development Session (FHP) is

a program of providing conditional social assistance to poor families who are designated as KPM FHP, measured by a questionnaire.

Maternal education is the last formal education level taken by study subjects until they get a certificate, measured by a questionnaire.

Family income is the total of all income generated by the head of the family and the mother, either regular or side income in a month and expressed in Rupiah currency, measured by a questionnaire.

Social support is the support provided to study subjects in the form of good behavior 
such as emotional support, information support and real support from husbands, family and friends related to child nutritional status.

Maternal knowledge is a cognitive ability that a mother has related to her knowledge of nutritional status and child visit to integrated community health center.

Self-efficacy is the belief or confidence of the study subject's mother regarding her ability to maintain child nutritional status.

Complementary feeding is the provision of additional food to children according to the child's age after being given exclusive breastfeeding.

Toddler visits to integrated community health center are the presence of toddlers who have come to IHC to participate in IHC activities in the last 6 months, measured by a questionnaire.

Integrated community health center is a community center for health services and family planning.

Table 1. Sample Characteristics

\begin{tabular}{lr}
\hline \multicolumn{1}{c}{ Characteristics } & Freque \\
\hline Maternal Age & \\
$<31$ years old & \\
$\geq 31$ years old & 101 \\
Child Gender & \\
Male & 98 \\
Female & 10 \\
Child Age & \\
$<3$ years old & 128 \\
$\geq 3$ years old & 72 \\
\hline
\end{tabular}

Based on table 1, it shows that the characteristics of mothers aged $\geq 31$ years old were 101 subjects (50.5\%), the children gender was mostly female (51.0\%) with age $<3$ years were 128 subjects (64.0\%).

\section{BivariateAnalysis}

Bivariate analysis was used to examine the relationships between the independent Fa-

\section{Data Analysis}

Univariate analysis to analyze the frequency distribution and percentage of the characteristics of the study subjects. Bivariate analysis to study the relationship between nutritional status of toddlers with independent variables using the chi-square. Multivariate analysis used multilevel levels with STATA.

\section{Research Ethic}

Research ethics include informed consent, anonymity, confidentiality and ethical clearances. Ethical clearance in this study was conducted at Medical School of UNS Surabaya on 20 December 2019. Number: 007/ UN27.06/ KEPK/2020.

\section{RESULTS}

\section{Sample Characteristics}

The subjects of this study were 200 children in Ponorogo. The frequency distribution of the characteristics of the study subjects is described in table 1. 
Table 2. Bivariate Analysis

\begin{tabular}{|c|c|c|c|c|c|c|c|c|}
\hline \multirow{3}{*}{ Independent Variables } & \multicolumn{4}{|c|}{ Child Nutritional Status } & \multirow{2}{*}{\multicolumn{2}{|c|}{ Total }} & \multirow{3}{*}{$\mathbf{O R}$} & \multirow{3}{*}{$\mathbf{p}$} \\
\hline & \multicolumn{2}{|c|}{ Abnormal } & \multicolumn{2}{|c|}{ Normal } & & & & \\
\hline & $\mathbf{N}$ & $\%$ & $\mathbf{N}$ & $\%$ & $\mathbf{N}$ & $\%$ & & \\
\hline \multicolumn{9}{|l|}{ Family Development Session } \\
\hline Not Participated & 60 & 60.0 & 40 & 40.0 & 100 & 100 & 2.55 & 0.001 \\
\hline Participated & 37 & 37.0 & 63 & 63.0 & 100 & 100 & & \\
\hline \multicolumn{9}{|l|}{ Maternal Education } \\
\hline$<$ Senior high school & 73 & 67.0 & 36 & 33.0 & 109 & 100 & 5.66 & $<0.001$ \\
\hline$\geq$ Senior high school & 24 & 26.4 & 67 & 73.6 & 91 & 100 & & \\
\hline \multicolumn{9}{|l|}{ Family Income } \\
\hline$<\operatorname{Rp} 1,000,000$ & 69 & 69.7 & 30 & 30.3 & 99 & 100 & 5.60 & $<0.001$ \\
\hline$\geq \operatorname{Rp} 1,000,000$ & 28 & 27.7 & 73 & 72.3 & 101 & 100 & & \\
\hline \multicolumn{9}{|l|}{ Social Support } \\
\hline Weak & 68 & 70.1 & 29 & 29.9 & 97 & 100 & 5.98 & $<0.001$ \\
\hline Strong & 29 & 28.2 & 74 & 71.8 & 103 & 100 & & \\
\hline \multicolumn{9}{|l|}{ Maternal Knowledge } \\
\hline Poor & 65 & 69.9 & 28 & 30.1 & 93 & 100 & 5.44 & $<0.001$ \\
\hline Good & 32 & 29.9 & 75 & 70.1 & 107 & 100 & & \\
\hline \multicolumn{9}{|l|}{ Self Efficacy } \\
\hline Low & 68 & 64.8 & 37 & 35.2 & 105 & 100 & 4.18 & $<0.001$ \\
\hline High & 29 & 30.5 & 66 & 69.5 & 95 & 100 & & \\
\hline \multicolumn{9}{|l|}{ Complementary Food } \\
\hline No & 62 & 62.0 & 38 & 38.0 & 100 & 100 & 3.03 & $<0.001$ \\
\hline Yes & 35 & 35.0 & 65 & 65.0 & 100 & 100 & & \\
\hline \multicolumn{9}{|l|}{$\begin{array}{l}\text { Child visit to integrated } \\
\text { community health center }\end{array}$} \\
\hline Not Active & 75 & 79.8 & 19 & 20.2 & 94 & 100 & 15.07 & $<0.001$ \\
\hline Active & 22 & 20.8 & 84 & 79.2 & 106 & 100 & & \\
\hline
\end{tabular}

The results of the Chi square correlation test showed that there was a significant relationship between the Family Development Session and the nutritional status of toddlers $(\mathrm{OR}=2.55 ; \mathrm{p}=0.001)$. Children who participate in the Family Development Session were 2.55 times more likely to have normal nutritional status compared to children who did not participate in the Family Development Session.

There was a significant relationship between maternal education and child nutritional status $(\mathrm{OR}=5.66 ; \mathrm{p}<0.001)$. Mothers with $\geq$ Senior high school education were 5.66 times more likely to have toddlers with normal nutritional status than mothers with < Senior high school.

There was a significant relationship between family income and nutritional status of toddlers $(\mathrm{OR}=5.60 ; \mathrm{p}<0.001)$. Toddlers with a family income of $\geq R p$ $1,000,000$ were 5.60 times more likely to have a normal nutritional status compared to toddlers with a family income of $<\mathrm{Rp}$ $1,000,000$.

There was a significant relationship between social support and nutritional status of toddlers $(\mathrm{OR}=5.98 ; \mathrm{p}<0.001)$. Mothers with strong social support were 5.98 times more likely to have toddlers with normal nutritional status than mothers with weak social support.

There was a significant relationship between maternal knowledge and child nutritional status $(\mathrm{OR}=5.44 ; \mathrm{p}<0.001)$. Mothers with good knowledge were 5.44 times more likely to have toddlers with 
normal nutritional status compared to mothers with lack of knowledge.

There was a significant relationship between self-efficacy and nutritional status of toddlers (OR $=4.18 ; \mathrm{p}<0.001)$. Mothers with high self-efficacy were 4.18 times more likely to have toddlers with normal nutritional status than mothers with low selfefficacy.

There was a significant relationship between complementary foods and nutritional status of toddlers $(\mathrm{OR}=3.03 ; \mathrm{p}$ $<$ o.001). Toddlers who were given complementary foods were 3.03 times more likely to have normal nutritional status than those who did not consume complementary foods.

There was a significant relationship between toddlers visits to IHC and nutritional status of toddlers $(\mathrm{OR}=15.07 ; \mathrm{p}$ <0.001). Toddlers with active IHC visits have 15.07 times the chance of having normal nutritional status compared to toddlers who were not actively visiting the integrated community health center.

\section{Multilevel Analysis}

Multilevel analysis on STATA was used to determine the effect of variables level 1 and 2 on the variable of toddlers' nutritional status.

There was an effect of FDS on the nutritional status of toddlers, this effect was statistically significant. Toddlers who followed FDS had a higher logodd for normal nutritional status than those who did not follow FDS (OR=1.24; 95\% CI= $0.26-2.22 ; p=0.014)$.

There was an effect of maternal education on the nutritional status of toddlers, this effect was statistically significant. Toddlers with maternal education who were $\geq$ HS have a higher logodd for normal nutritional status than toddlers with maternal education <Senior high school (OR= 1.18; 95\% CI= $0.16-2.19 ; \mathrm{p}=0.023)$.
There was an effect of family income on the nutritional status of toddlers, this effect was statistically significant. Toddlers with family income of $\geq$ Rp. 1000000 have a higher logodd for normal nutritional status than toddlers with family income of $<$ Rp. 1000000. $(\mathrm{OR}=1.11 ; 95 \% \mathrm{CI}=0.11-$ 2.11; $\mathrm{p}=0.030)$.

There was an effect of social support on the nutritional status of toddlers, this effect was statistically significant. Toddlers with strong social support have a higher logodd for normal nutritional status than toddlers with weak social support (OR= 1.57; 95\% CI= $0.46-2.67 ; \mathrm{p}=0.006)$.

There was an effect of maternal knowledge on the nutritional status of toddlers, this effect was statistically significant. Children with good maternal knowledge have a higher logodd for normal nutritional status than toddlers with lack of maternal knowledge $(\mathrm{OR}=1.24 ; 95 \% \mathrm{CI}=0.26-2.23$; $\mathrm{p}=$ 0.013).

There was an effect of self efficacy on the nutritional status of toddlers, this effect was statistically significant. Toddlers with high maternal self-efficacy have a higher logodd for normal nutritional status than toddlers with mothers who have low selfefficacy $(\mathrm{OR}=1.38 ; 95 \% \mathrm{CI}=0.32-2.44 ; \mathrm{p}=$ o.011).

There was an effect of complementary foods on the nutritional status of toddlers, this effect was statistically significant. Toddlers who got complementary foods have a higher logodd for normal nutritional status toddlers who did not get complementary foods $(\mathrm{OR}=1.35 ; 95 \% \mathrm{CI}=0.33-2.37$; $\mathrm{p}=0.010)$.

There was an effect of toddlers' visits to IHC on the nutritional status of toddlers, this effect was statistically significant. Toddlers with active IHC visits have a higher logodd for normal nutritional status than toddlers with non-active IHC visit 
$(\mathrm{OR}=1.42 ; 95 \% \mathrm{CI}=0.28-2.56 ; \mathrm{p}=$ 0.015).Based on the data analysis, the ICC result $=33.97 \%$. These indicators showed that the variation in nutritional status of toddler was $33.97 \%$ determined by the IHC.

Table 3. The results of multilevel analysis

\begin{tabular}{|c|c|c|c|c|}
\hline \multirow[b]{2}{*}{ Child Nutritional Status } & \multirow[b]{2}{*}{ OR } & \multicolumn{2}{|c|}{$95 \% \mathrm{CI}$} & \multirow[b]{2}{*}{$\mathbf{p}$} \\
\hline & & Lower Limit & $\begin{array}{c}\text { Upper } \\
\text { Limit }\end{array}$ & \\
\hline \multicolumn{5}{|l|}{ Fixed Effect } \\
\hline FDS (participated) & 1.24 & 0.26 & 2.22 & 0.014 \\
\hline Maternal education ( $\geq$ HS) & 1.18 & 0.16 & 2.19 & 0.023 \\
\hline Family income ( $\geq \operatorname{Rp} 1,000,000)$ & 1.11 & 0.11 & 2.11 & 0.030 \\
\hline Social support (strong) & 1.57 & 0.46 & 2.67 & 0.006 \\
\hline Maternal knowledge (good) & 1.24 & 0.26 & 2.23 & 0.013 \\
\hline Self efficacy (high) & 1.38 & 0.32 & 2.44 & 0.011 \\
\hline Complementary food (yes) & 1.35 & 0.33 & 2.37 & 0.010 \\
\hline Child visits to IHC (active) & 1.42 & 0.28 & 2.56 & 0.015 \\
\hline \multicolumn{5}{|l|}{ Random Effect } \\
\hline \multicolumn{5}{|l|}{ Integrated Healthcare Center (IHC) } \\
\hline Var (ConstantS) & 1.69 & 0.50 & 5.72 & \\
\hline $\mathrm{N}$ observation $=225$ & & & & \\
\hline Log likelihood $=-73.17$ & & & & \\
\hline LR test vs. linier regression, $p=0.003$ & & & & \\
\hline $\mathrm{ICC}=33.97 \%$ & & & & \\
\hline
\end{tabular}

\section{DISCUSSION}

1. The effect of Family Development Session on child nutritional status

The results of this study indicated that there was an effect of FDS on the nutritional status of toddlers. The results of this study are in accordance with study done by Kuntjorowati (2018) which states that FDS is one of the determinants of factors that affect the nutritional status of toddlers. This is because in the FDS meeting, PKH Facilitators provide health education related to the importance of the nutritional status of toddlers to increase the growth and development of toddlers optimally.

Prayitna et al. (2018) showed that $85 \%$ of mothers who bring their toddlers to the IHC to check the weight of their children increase after joining the $\mathrm{PKH}$ program, the sanctions given if PKH participants do not visit IHC are one of the factors that influence the increased activity of IHC visits and have a positive effect on the nutritional status of toddlers.

\section{The effect of maternal education on child visits to IHC}

The results of this study indicated that there was an effect of maternal education on the child nutritional status. Parents in the family are role models for their children, especially mothers. Mothers with high education have the possibility to have high knowledge about the importance of maintaining children's health, one of them is by maintaining the nutritional status of toddlers and early detection of children's health problems to support optimal growth and development(Anjani, 2018).

Maternal education is one of the basic factors that are important for the growth and child development so as to achieve good toddler health (Rahayu and Khairiyati, 2014). The level of maternal education is useful in terms of the ease with which the mother receives information about nutrition and health problems from outside. The role of mothers as the primary caregivers of their children is very much needed, one of 
them is related to purchasing and serving food to improve nutritional status.

\section{The effect of family income on child nutritional status}

The results of this study indicated that there was an effect of family income on the nutritional status of toddlers. Families with low income will experience difficulties in fulfilling their daily needs, but if the increase in income obtained is not fully used to fulfill foods that contain lots of high nutrition, the family's nutritional intake needs are also not able to be fulfilled, therefore, it is necessary to manage family income properly which is useful to improve the nutritional status of the family, especially toddlers (Knight et al., 2015).

Family income, especially in the first 1000 days of life, increases the development of children, thereby reducing nutritional problems in toddlers, one of them is stunting. Family socio-economics are always associated with health aspects for children's growth and development that have an impact on future life Families with high income will have the ability to meet nutritional needs and choose good health services for children so that they will prevent infectious diseases which is due to good early detection (Conant et al., 2017). Family income has an important role, especially in affecting the standard of living. The effect is more oriented towards welfare and health, where an increase in income will increase the nutritional level of the community (Nshimyiryo et al., 2019).

\section{The effect of social support on child nutritional status}

The results of this study indicated that there was an effect of social support on the nutritional status of toddlers. Mustafyani (2017) explained that mothers with weak social support have an effect on maternal anxiety related to children's health compared to mothers who have strong support, this shows that social support has an important role in improving the nutritional status of the family. Social support, especially husbands, is also one of the other reinforcing factors that affect the nutritional status of toddlers through the implementation of a nutritionally aware family (Kadarzi).

According to Saputri, Sulistiyana and Rohmawati (2016), the most important social support is husband's support. The four types of social support are emotional, rewarding, instrumental and informative support. Husband's social support has an influence in making the final decisions for the wife's actions so that the mother can make the best decisions in case of health problems that can reduce nutritional status.

\section{The effect of maternal knowledge on child nutritional status}

The results of this study indicated that there was an effect of maternal knowledge on the child nutritional status. Knowledge is one of the factors that influence a person's behavior regarding skills and practices based on social cognitive theory (Bandura, 2002).

Mothers with high nutritional knowledge are expected to be able to influence maternal parenting related to age-appropriate feeding for toddlers so that child nutrition remains normal because toddlers get nutrition that is in accordance with the needs and good knowledge of mothers regarding early detection of health problems in children can help mothers to monitor and prevent the occurrence of health problems that can reduce the child nutritional status (Amalia et al., 2019). Mothers who have a higher level of nutritional knowledge will provide a nutritionally balanced diet with lots of vegetables, fruit and nuts so that the level of maternal nutritional knowledge becomes one of the factors that play a role in maintaining 
normal nutritional status for children, for example through the intake of food consumed by toddlers Yabancı et al., 2014). Fadare et al. (2019) also explained that maternal knowledge is an important factor to improve the nutritional status of toddlers.

\section{The effect of maternal self efficacy on child nutritional status}

The results of this study indicated that there was an effect of maternal self efficacy on the nutritional status of toddlers. Abdullah (2019)explained that self-efficacy is related to behavior change which is part of the idea of social cognitive theory. The focus of the SCT idea is the result of the reciprocal interaction between the three behavioral factors, namely reciprocal determinants, social norms and cognitive factors.

Kurniavie and Murti (2020) explained that the mother's self-efficacy can improve their behavior to visit health facilities and health services such as IHC with the existence of health education, one of them is related to the importance of nutritional benefits for children, with high self-efficacy, mothers can improve the nutritional status of toddlers. Ernawati et al. (2018) also show that maternal selfefficacy can affect the nutritional status of toddlers through toddler visits to IHC $(\mathrm{OR}=$ $1.90 ; p=0.011$ ), so that children who actively visit IHC are expected to receive monitoring of nutritional status.

\section{The effect of complementary food on child nutritional status}

The results of this study indicated that there was an effect of complementary food on the nutritional status of toddlers. The indicators that need to be considered in providing complementary foods are age, type, frequency of provision, and portion of complementary foods (Lestari, Margawati and Rahfiludin, 2014). The similar thing is also explained by Handayani et al. (2017) who stated that complementary feeding is associated with various predisposing factors such as attitudes and knowledge of mothers regarding complementary feeding.

According to Gusti (2011), a good maternal knowledge is one of the determinants factors that influence exclusive breastfeeding so that children are given complementary foods on time. Khanal et al., (2013) explained that the benefits of in time complementary food have a positive effect on exclusive breastfeeding so that it can support the growth and development of toddlers. Babies who are exclusively breastfed tend to have a taller height and conform to a growth curve than babies who are given complementary food too early.

\section{The effect of toddlers visits to IHC on child nutritional status}

The results of this study indicated that there was an effect of toddler visits to IHC on the nutritional status. The results of this study are in line with the research of Sugiarti et al., (2014) which showed that children who actively visit IHC have a higher percentage of good nutritional status (62.5\%) than those who are not active (10\%). Asdhany and Kartini (2012) also explained that the level of participation of mothers in IHC activities affects the nutritional status of toddlers based on weight/ age. Based on this explanation, it can be concluded that the results of the study showed that child visits to posyandu could improve their nutritional status.

\section{The effect of integrated community health center on child nutritional status}

The results of the study with multilevel analysis showed that the ICC $=33.97 \%$. These indicators show that the IHC conditions at each stratum have an environmental effect on the variation in nutritional status of toddlers by $33.97 \%$, so the envi- 
ronmental influence, namely the IHC, which is shown from the multilevel analysis is very important. The concept of environmental factors, namely environmental situations can affect someone's thinking and behavior so that it affects health status (Sulaeman, 2016). According to Lanoh and Karundeng (2015), there is a significant relationship between the use of IHC and the nutritional status of their children. According to Priyatiningsih and Nurwahyuni (2019), regular IHC visits can improve early detection of related to child's nutrition problems, such as obesity, but on the other hand, mothers with low education have the possibility to not actively visit IHC because of their low knowledge about the role of IHC visits for their children.

\section{AUTHOR CONTRIBUTION}

Nisaus Zakiyah, the main researcher has a role in collecting and processing research data; Endang Sutisna Sulaeman examined the conceptual framework and study methodology; Eti Poncorini Pamungkasari examined the results of the study.

\section{CONFLICT OF INTEREST}

There was no conflict of interest in this study.

\section{FUNDING AND SPONSORSHIP}

This study used personal funds from the main researcher.

\section{ACKNOWLEDGEMENT}

The researchers would like to thank Endang Sutisna Sulemandan and Eti Poncorini Pamungkasari who have studied this research. The researchers are also thankful to the Community Health Center and Integrated Healthcare Center in Ponorogo Regency who have helped this study and also mothers and toddlers who have participated and were willing to be the study subjects.

\section{REFERENCE}

Abdullah SM. (2019). Social cognitive theory: a bandura thought review published in 1982-2012. Jurnal Psikodimensia, 18(1): doi: 10.24167/psidim.v18i1.1708.

Amalia E, Syahrida S, Andriani Y (2019). Faktor mempengaruhi kunjungan ibu membawa balita ke posyandu kelurahan tanjung pauh tahun 2018. Perintis's Health Journal, 6(1): 6067. doi: 10.33653/jkp.v6i1.242.

Anjani AD (2018). Faktor faktor yang berhubungan dengan ibu yang membawa balita timbang ke posyandu (Factors related to mothers who weigh their children to the posyandu). Jurnal Kebidanan, 4(2): 49-53. doi: 10.1017/cbo9781107415324.004.

Asdhany C, Kartini A (2012). Hubungan tingkat partisipasi ibu dalam kegiatan posyandu dengan status gizi anak balita (The relationship between the level of participation of mothers in posyandu activities with the nutritional status of toddlers). Journal of Nutrition College, 1(1): 11-20.

Bandura A (2002). Social cognitive theory in cultural context. applied psychology: an international review. 51: 269-290.

Conant RT, Six J,Paustian K (2003). land use effects on soil carbon fractions in the southeastern united states. i. Management-intensive versus extensive grazing. Biology and Fertility of Soils, 38(6): 386-392. doi: 10.1007/s00374-003-0652-z.

Ernawati A., Sulaeman ES. dan Indarto D. (2018). Associations of self-efficacy, family support, peer support, and posyandu facility, with mother's visit to posyandu. Journal of Maternal and Child Health, 3(3): 233-241. 
Fadare O, Amare U, Mavrotas G, Akerele D, Ogunniyi A (2019). Mother's nutrition-related knowledge and child nutrition outcomes: empirical evidence from nigeria. Plos ONE, 14(2):1-17.

Gusti D, Bachtiar H, Masrul (2011). Promosi asi eksklusif memakai metode konseling dengan penyuluhan pengetahuan dan sikap ibu menyusui (Exclusive promotion using the method of counseling with knowledge and attitudes of breastfeeding mothers). Jurnal Kesehatan Masyarakat,6(1).

Handayani DO, Pamungkasari EP, Budihastuti UR (2018). Mother's education as a determinant of stunting among children of age 24 to 59 months in north sumatera province of indonesia.IOSR, 22(06): 58-64. doi: 10.9790/0837-2206095864.

Kemensos (2016). Pedoman umum program keluarga harapan tahun 2016 (General guidelines for Family Hope Program in 2016). Jakarta. Dirjen perlindungan dan jaringan.

Kemensos RI (2017). Kebijakan pelaksanaan program keluarga harapan tahun 2017 (The implementation of Family Hope Program policy in 2017). Jakarta. Dirjen perlindungan dan jaringan.

Kementerian Kesehatan (2012). Buku pegangan kader posyandu (Posyandu cadre handbook). Jakarta.dirjen perlindungan dan jaringan .

Khanal V, Sauer K, Zhao Y (2013). Exclusive breastfeeding practices in relation to social and health determinants: a comparison of the 2006 and 2011 nepal demographic and health surveys. BMC Public Health, 13: 958.

KnightM,Tuffnel D, Kenyon S, Shakespeare J, Gray R, Kurinczuk JJ (2015). Mbrrace-uk: saving lives, improving mothers' care. surveillance of maternal deaths in the uk maternal, new- born and infant clinical outcome review programme. HQIP. https://www.npeu.ox.ac.uk/mbrrace-uk/reports.

Kuntjorowati E (2018). Pengaruh pemberdayaan keluarga penerima manfaat program keluarga harapan (The effect of empowering the beneficiary family of the family hope program). Jurnal PKS, 17: 89-100.

Kurniavie LE, Murti B (2020).The association between the integrated health post activity and the performance of community health workers in child growth and development care service in Karanganyar, Central Java. 5(1): 48-6o.

Lanoh M,Karundeng M (2015). Hubungan pemanfaatan posyandu dengan status ranotana weru Kota Manado (The relationship between posyandu utilization and the status of Ranotana weru in Manado City).3.

Lestari W, Margawati A, Rahfiludin MZ (2014). Faktor risiko stunting pada anak umur 6-24 bulan di kecamatan penanggalan Kota Subulussalam Provinsi Aceh (Risk factors for stunting in children aged 6-24 months in the Penanggalan Sub-district, Subulussalam City, Aceh Province), 3(1): 37-45.

LIPI (2018). Outlook ekonomi 2018 proyeksi (Economic Outlook 2018 projections).

Mustafyani (2017). Hubungan pengetahuan, sikap, dukungan suami, kontrol perilaku, dan niat ibu dengan perilaku kadarzi ibu balita gizi kurang (The relationship between knowledge, attitudes, husband's support, behavior control, and mother's intentions with malnutrition toddlers). Indones $\mathrm{J}$ Public Health, 12(2): 190-201. doi: 10.20473/ijph.v12i1.2017.190-201.

Nshimyiryo A. et al. (2019). RIsk factors for 
stunting among children under five years: a cross-sectional populationbased study in rwanda using the 2015 demographic and health survey. BMCPublic Health, 19(1): 1-10. doi: 10.1186/s12889-019-6504-z.

OliveiraJS, et al. (2013). Fatores associados ao estado nutricional em crianças de creches públicas do município de recife, pe, Brasil.revista brasileira de epidemiologia, 16(2): 502-512. doi: 10.1590/s1415-790x2013000200024.

Parsons SA,et al. (2015). Students' engagement in literacy tasks.reading teacher, 69(2): 223-231. doi: 10.1002/trtr.1378.

Prayitna (2018). Evaluasi program keluarga harapan dalam meningkatkan keberdayaan perempuan di bidang pendidikan dan kesehatan (Evaluation of the family hope program in increasing women's empowerment in the education and health sectors). 13(1): 67-75. doi: 10.1017/cbo9781107415324.004.

Priyatiningsih N, Nurwahyuni A (2019). The effect of utilizing health operational assistance funds on children' $s$ health efforts through on integrated health center (IHC) in Indonesia based on 2014 ifls data. 15(3): 311317.

Rahayu A, Khairiyati L (2014). Risiko pendidikan ibu terhadap kejadian stunting pada anak 6-23 bulan (The risk of mother's education on the incidence of stunting in children aged 6-23 months). Penel Gizi Makan, 37(ci): 129-136. doi: 10.22435/pgm.v37i2.4016.129-136.

Saputri IM, Sulistiyana, Rohmawati N (2016). Peran dan fungsi kader, dukungan sosial suami, dan pengetahuan tentang budaya keluarga pada pelaksanaan Keluarga Sadar Gizi (The role and function of cadres, husband's social support, and knowledge of family culture in the implementation of a Nutrition Awareness Family). Jurnal Kesehatan, 4(1): 168-174.

Sugiarti (2014). Kepatuhan kunjungan posyandu dan status gizi balita di posyandu (Compliance with posyandu visits and nutritional status of children at posyandu). Journal Ners and Midwefery Indonesia, 3(2): 141146.

Sulaeman ES (2016). Promosi kesehatan: teori dan implementasi di Indonesia (Health promotion: theory and implementation in Indonesia). Surakarta. UNS Press.

Yabancı N, Kısaçİ,Karakuş SŞ (2014). The effects of mother's nutritional knowledge on attitudes and behaviors of children about nutrition.Social and Behavioral Sciences, 116: 4477-4481. doi: 10.1016/j.sbspro.2014.01.970. 